\title{
Rhizophagus intraradices improves arsenic tolerance in Sophora viciifolia Hance
}

\author{
Qiaoming Zhang ${ }^{1}$, Minggui Gong ${ }^{2^{*} \mathbb{D}}$, Shanshan $\mathrm{Xu}^{1}$, Yanan Wei ${ }^{1}$, Jiangfeng Yuan ${ }^{2}$ and Qingshan Chang ${ }^{1}$
}

\begin{abstract}
Purpose: Arbuscular mycorrhizal fungi (AMF) are capable of protecting host plants against heavy metal toxicity, whereas rare knowledge has been acquired on the underlying effects of AMF on woody leguminous species under arsenic (As) stress. This study was aimed that whether AMF inoculation improves the As tolerance in Sophora viciifolia (a king of leguminous shrub).

Methods: S. viciifolia seedlings were inoculated with AMF Rhizophagus intraradices, and then the seedlings were

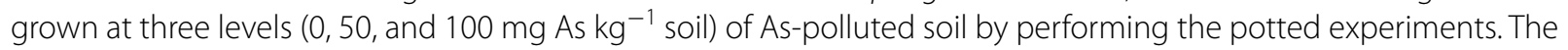
plant growth, photosynthetic parameter, oxidative damage, antioxidant enzyme activities and gene expression of phytochelatin synthase in $R$. intraradices- and non-inoculated $S$. davidii seedlings under the different levels of As stress were analyzed.

Result: Compared with non-inoculated S. viciifolia at the identical As level, R. intraradices-inoculated S. viciifolia were higher in the shoot and root dry weight, plant height, root length, photosynthetic rate, stomatal conductance, transpiration rate, maximal photochemical efficiency of PSII photochemistry, actual quantum yield, and photochemical quenching values, while the intercellular $\mathrm{CO}_{2}$ concentration and non-photochemical quenching values were lower. As-induced oxidative stress generating malondialdehyde, hydrogen peroxide and superoxide in the S. viciifolia leaves and roots reduced significantly by $R$. intraradices inoculation, whereas the activities of antioxidative enzymes (e.g., superoxide dismutase, peroxidase, and catalase) in S. viciifolia leaves and roots were increased by $R$. intraradices inoculation. Notably, R. intraradices inoculation up-regulated the gene expression of S. viciifolia phytochelatins in the leaves and roots.
\end{abstract}

Conclusion: These results demonstrated that $R$. intraradices inoculation enhanced the As tolerance in S. viciifolia seedlings by improving the plant growth, gas exchange, chlorophyll fluorescence, reactive oxygen species, antioxidant enzymes and gene expression of S. viciifolia phytochelatins. The present study verified a multifarious positive role of AMF for woody leguminous species under As stress.

Keywords: Arbuscular mycorrhizal fungi, Sophora davidii, Arsenic stress, Photosynthesis, Reactive oxygen species, PCS1 gene expression

*Correspondence: gongminggui@163.com

${ }^{2}$ College of Food and Bioengineering, Henan University of Science and Technology, Luoyang 471023, Henan, China

Full list of author information is available at the end of the article

\section{Introduction}

Arsenic (As) is an ubiquitous "heavy metal" (HM) element in the earth crust ( $\mathrm{Li}$ et al. 2019), and the normal As content in soil and water does not exceed $10 \mathrm{mg} \mathrm{kg}^{-1}$ (Gomes et al. 2015; Li et al. 2018). Over the past decades, As accumulation in agricultural products beyond the threshold values has seriously jeopardized human health through food chains in many places on earth ( $\mathrm{Li}$ et al. 
2019). As contamination has been progressively worse as impacted by excessive anthropogenic activities (Das et al. 2017a, b; De Andrade et al. 2015; Sharma et al. 2017; Zhang et al. 2017). Excess As in the terrestrial ecosystem have a negative influence on the growth and development of higher plants (Li et al. 2019). As ions in the natural ecosystems are often absorbed into the root hair cells by the non-specific transporters of plasma membrane (Gomes et al. 2015; Luo et al. 2016). As in plant cells suppresses the cytoplasmic enzymatic activities, and then superfluous free radicals (FR) and reactive oxygen species (ROS) are subsequently formed in plant tissues (Sharma et al. 2017; Srivastava et al. 2007). As a result, the oxidative damages of cell structures, suppression of photosynthesis, reductions in plant growth and yield are caused with increasing oxidation and radical chain reactions, and vegetation degradation ultimately occur in some Ascontaminated areas (Das et al. 2017a, b; De Andrade et al. 2015; Sharma et al. 2017; Spagnoletti et al. 2017).

Higher plants possess the detoxification and repair system to improve the As tolerance. The antioxidative enzymatic system, that produces antioxidant enzymes, is capable of scavenging FR and ROS to prevent oxidative damage in plant cells (Srivastava et al. 2007). Moreover, plants induce the adaptive detoxification mechanisms of phytochelatins (PCs) to alleviate HM stress ( $\mathrm{Li}$ et al. 2019). PCs chelate $\mathrm{HM}$ ions (e.g., $\mathrm{Pb}, \mathrm{Cd}, \mathrm{Hg}, \mathrm{Cu}, \mathrm{Cr}$, and As), and the formative stable $\mathrm{PC}-\mathrm{HM}$ compounds are subsequently transported from the cytosol to the vacuoles of plant cell, accordingly, the HM toxicity can be neutralized and alleviated (Das et al. 2017a, b; Xu et al. 2014). In recent years, $P C S$ genes in some higher plants are isolated and described, and the overexpression of Arabidopsis PCS genes in other plant species are proved to directly increase the HM tolerance (Li et al. 2019).

Arbuscular mycorrhizal fungi (AMF) are capable of developing symbiotic relationships with over $80 \%$ of terrestrial higher plants, which include those growing in As-contaminated environments (Sharma et al. 2017; Shi et al. 2017; Smith and Read 2008). AMF are critical as a "bridge" between plants and rhizosphere soil, they acquire carbohydrate compounds and lipids from host plants, and in return transfer mineral nutrients from rhizosphere soil to host plants via their arbuscules and hyphal coils, when host plants cannot acquire easily (Gong et al. 2013; Riley and Corradi 2013). The widely recognized mechanism on AMF improving the As tolerance in host plants is the "growth dilution effect," which indicates that AMF assist host plants to improve the growth and to keep the higher phosphate/arsenate ratios in plant tissues ( $\mathrm{Li}$ et al. 2018; Spagnoletti and Lavado 2015; Zhang et al. 2020). Hymenoscyphus ericae, an ericoid mycorrhizal fungi, helps Calluna vulgaris to maintain low As levels in host plants by inhibiting cellular arsenic to arsenite and excluding arsenite from plant cells (Sharples et al. 2000). It is also proved that AMF can facilitate the high-affinity P/As transfer into Holcus lanatus roots (Gonzalez-Chavez et al. 2002). AMF symbiosis also improve the As tolerance in host plants by regulating some gene expression of host plants. AMF (Glomus intraradices) inoculation downregulates the expression of the HvPht1gene (encoding high-affinity inorganic orthophosphate (Pi)-uptake systems directly via root epidermis and root hairs) in Hordeum vulgare, thus, decrease the uptake of As in barley roots of $H$. vulgare (Christophersen et al. 2009). G. intraradices-induced expression of GiPT (highaffinity $\mathrm{Pi} / \mathrm{As}$ transporter) gene shows a correlation with As uptake within the external hyphae (González-Chávez et al. 2011). Whereas necessary information regarding the gene expression of PCS in AMF-inoculated plants under As stress has been scarce.

Sophora viciifolia Hance. is a type of vigorous perennial leguminous shrub. Such species is characterized by its developed root system, high survival rate, fast growth rate, and prominent adaptability to harsh environments (e.g., nutrient depletion, drought, salinity and HM) (Das et al. 2017a, b; Xu et al. 2014). Pb toxicity for S. viciifolia seedlings is alleviated by the AMF (Funneliformis mosseae) symbiosis, and the $F$. mosseae inoculation upregulates the expression of SvPCS1 gene in the roots under $\mathrm{Pb}$ stress (Xu et al. 2014). S. viciifolia has been extensively distributed in warm-temperate to subtropical areas of China, and these areas are generally polluted by As in different degrees. However, rare information on the AMFinoculated S. viciifolia seedlings under As stress has been reported. In the present study, a pot experiment was performed to explore the effects of Rhizophagus intraradices on the plant growth, photosynthesis, reactive oxygen species, antioxidant enzymes, and genetic expression of SvPCS1 in S. viciifolia seedlings at the different levels of As stress. The aim was to determine the related physiological and molecular mechanisms on AMF improving the As tolerance in S. viciifolia seedlings. If AMF-inoculated S. viciifolia seedlings have the better growth performance than non-inoculated seedlings under As stress, AMF-inoculated S. viciifolia might be considered an ideal pioneer tree species in As-contaminated soil.

\section{Materials and methods}

\section{Experimental design}

The experiment of this study consisted of six treatments, which was set in a complete randomized block design with two factors below: (1) AMF treatments, i.e., $R$. intraradices and non-AMF inoculated control; (2) three available As concentrations in soils, i.e., 0, 50, and $100 \mathrm{mg} \mathrm{As/}$ $\mathrm{kg}$ dry soil. By complying with the established standard 
for the grade of As pollution in Risk Control Standard of Soil Pollution in Agricultural Land in China (GB 156182018), when the As content in farmland soil exceeded $100 \mathrm{mg} / \mathrm{kg}$, it would be considered high risk, and the soil was forbidden to plant agricultural products. Besides, when the $50 \mathrm{mg} / \mathrm{kg}$ As content in soil was identified as a middle-level pollution, agricultural products would be controlled by Food and Drug Administration. Each of the six treatments contained three replicates, so there were a total of 18 pots (one seedling per pot).

\section{Growth substrate}

Farmland topsoil $(5-20 \mathrm{~cm})$ was collected from the campus of the Henan University of Science and Technology (HAUST), Henan Province, China. Subsequently, the soils were mixed with the sand and organic matter (soil, sand, and organic matter at 3:1:1, v/v/v). The physicochemical properties of mixed soil were as follows:, organic matter $50.52 \mathrm{~g} \mathrm{~kg}^{-1}$, available potassium 83.35 $\mathrm{mg} \mathrm{kg}^{-1}$, available nitrogen $40.52 \mathrm{mg} \mathrm{kg}^{-1}$, Olsen phosphorus $8.17 \mathrm{mg} \mathrm{kg}^{-1}$, and $\mathrm{pH} 7.8$ (1:5 soil:water ratio), and the extractable metal concentrations in soils were as follows: As 5.34, Fe 3.16, Mn 2.17, $\mathrm{Cu} \mathrm{0.14}$, and $\mathrm{Zn}$ $0.98 \mathrm{mgkg}^{-1} .5 .65 \mathrm{~g} \mathrm{Na}_{3} \mathrm{AsO}_{4} \cdot 12 \mathrm{H}_{2} \mathrm{O}$ dissolved in $1 \mathrm{~L}$ pure water, and then 0,50 and $100 \mathrm{~mL}$ arsenic solutions were respectively introduced into per $1 \mathrm{~kg}$ dry soil mixture. Then, the mixture was stirred completely with the blender. Lastly, three available As concentrations in soils $(0,50$, and $100 \mathrm{mg}$ As per kg dry soil) were prepared. For the mentioned potted experiment, the soil mixture was autoclaved for $2 \mathrm{~h}$ at $121{ }^{\circ} \mathrm{C}$ and $0.11 \mathrm{MPa}$ prior to the application.

\section{Plant material and growth conditions}

Sophora viciifolia seeds were collected in November 2016 from Shimen Realgar Mine (N 29 $38^{\prime} 32^{\prime \prime}$, E $111^{\circ} 2^{\prime} 17^{\prime \prime}$ ), Hunan Province. This mine acted as the largest producer of realgar in China. Plump S. viciifolia seeds were treated with $75 \%$ ethanol for $15 \mathrm{~min}$, washed with purified water, and then sowed in autoclaved wet sand at $28{ }^{\circ} \mathrm{C}$. In the previous study of the authors, the root morphological characteristics of S. viciifolia seedlings in conical frustum plastic containers containing $2 \mathrm{~kg}$ of soil mixture were suggested to have no obvious difference with those grown in field for three months (Zhang et al. 2020). After growing for 20 days, healthy seedlings were transplanted into conical frustum plastic containers with $2 \mathrm{~kg}$ of soil mixture contained. S. viciifolia received the cultivation in a solar greenhouse, the average temperature ranged from 15 to $25{ }^{\circ} \mathrm{C}$, and the temperature was regulated by using the ventilation system and the thermal insulation quilt. The relative humidity of the growth chamber ranged from 50\% to $80 \%$ from April to June 2016. All the treatments received a nutrient supplement of $500 \mathrm{~mL}$ Hoagland's solution ( $1.0 \mathrm{mmol} / \mathrm{L} \mathrm{NaH}_{2} \mathrm{PO}_{4}$ ) (Hoagland and Arnon 1950). To avoid the inhibition of AMF symbiosis by excessive $\mathrm{P}$ in soils, $50 \mathrm{~mL}$ modified Hoagland solution (containing only $25 \%$ of $\mathrm{P}, \quad 0.25 \mathrm{mmol} / \mathrm{L}$ $\mathrm{NaH}_{2} \mathrm{PO}_{4}$ ) was supplemented weekly, and the soil moisture was maintained at a field capacity of $70 \%$ by adding a certain amount of deionized water.

\section{Inoculation treatment}

AMF strain Rhizophagus intraradices (BGC BJ09) (N.C. Schenck \& G.S. Sm.) C. Walker and A. Schüßler originated from the Institute of Plant Nutrition and Resources, Beijing Academy of Agriculture and Forestry Sciences, Beijing, China. This AMF strain was proved to facilitate the plant growth, root morphology and phytohormone balance of Robinia Pseudoacacia in arsenic-contaminated soils (Zhang et al. 2020). Mycorrhizal inocula comprised a mixture of AMF spores (the spore density of 350 per $10 \mathrm{~g}$ dry sand soil), mycorrhizal hyphae, $R$. intraradices-infected clover root segments (average 73\% AMF colonization rate), as well as sandy soil. During the seedling transplantation, the respective pot in the mycorrhizal treatment was inoculated with 30 $\mathrm{g} R$. intraradices inoculumat a soil depth of $3-4 \mathrm{~cm}$, and the control non-inoculated plants received $30 \mathrm{~g}$ of heatsterilized inoculum (autoclaved at $121{ }^{\circ} \mathrm{C}$ for $30 \mathrm{~min}$ ) plus $50 \mathrm{ml}$ of microbial filtrate $(0.45 \mu \mathrm{m}$ pore size) to provide a similar microflora except for AM fungus.

\section{AMF colonization rate}

The AMF colonization in plant roots was detected by using 1-cm-long root fragments. The collected root fragments were washed with deionized water, soaked in $10 \% \mathrm{KOH}$ at $90{ }^{\circ} \mathrm{C}$ for $15 \mathrm{~min}$, decolorized in alkaline hydrogen peroxide $\left(3 \mathrm{~mL} \mathrm{NH} \mathrm{N}_{4} \mathrm{OH}, 30 \mathrm{~mL} 10 \% \mathrm{H}_{2} \mathrm{O}_{2}\right.$, $60 \mathrm{~mL} \mathrm{H}_{2} \mathrm{O}$ ) for $20 \mathrm{~min}$, and then acidified in $1 \% \mathrm{HCl}$ and stained with $0.05 \%(\mathrm{w} / \mathrm{v})$ trypan blue in lactophenol (Phillips and Hayman 1970). They were observed under the Microscope, and the AMF and arbuscules colonization rate was determined by using the grid-line intersect with the method presented by Giovannetti and Mosse (Giovannetti and Mosse 1980).

\section{Plant measurement}

After growing for three months, the physiological and biochemical parameters of $S$. viciifolia were analyzed. S. viciifolia seedlings were harvested. Soil which adhered to the root surface was removed with deionized water. A ruler was adopted to measure the plant height and the root length. Shoots and roots were divided to determine the separate fresh weights, and then they were weighed 
after receiving the oven drying at $70{ }^{\circ} \mathrm{C}$ for $48 \mathrm{~h}$ to obtain the dry weight.

\section{As and $\mathrm{P}$ content}

As and P content in the dry roots and leaves of S. viciifolia seedlings were extracted through the nitric acid digestion at $270{ }^{\circ} \mathrm{C}$, which were determined with a graphite furnace atomic absorption spectrophotometer (PerkinElmerAnalyst400, Norwalk, CT, USA) based on USEPA Method 7060A (Li et al. 2018).

\section{Chlorophyll content}

The total chlorophyll content was analyzed by complying with the method of Srivastava and Sharma (Ahmed et al. 2006). One gram of fresh leaves were crushed in $100 \mathrm{~mL}$ $80 \%$ acetone in ice-bath. The extracted solution was centrifuged at $2000 \times g$ for $10 \mathrm{~min}$. The absorbance of supernatant was measured spectrophotometrically at $645 \mathrm{~nm}$ and $663 \mathrm{~nm}$ with a spectrophotometer (Shanghai Jinghua 752). The chlorophyll content was expressed in terms of $\mathrm{mg}$ chlorophyll present/g fresh weight of tissues.

\section{Gas exchange and chlorophyll fluorescence}

Using a portable photosynthesis system LI-6400 (LICOR, Lincoln, NE, USA), the net photosynthetic rate $(\mathrm{Pn})$, the stomatal conductance (gs), the intercellular $\mathrm{CO}_{2}$ concentration $(\mathrm{Ci})$, and the transpiration rate $(\mathrm{E})$ were determined on the fifth expanded leaf of the respective plant. The analysis was performed at $2000 \mu \mathrm{mol} \mathrm{m}^{-2} \mathrm{~s}^{-1}$ active radiation, $350 \mathrm{~cm}^{3} \mathrm{~m}^{-3} \mathrm{CO}_{2}$ concentration, 25.0 ${ }^{\circ} \mathrm{C}$ leaf temperature and $0.5 \mathrm{dm}^{3} \mathrm{~min}^{-1}$ atmospheric flow rate between 9:30 and 11:00 a.m. during the data acquisition (Zhang et al. 2017).

The chlorophyll fluorescence parameters were determined with a modulated PAM-2000 portable fluorometer (Imaging-PAM, Walz, Germany) on the fifth expanded leaves of S. viciifolia. The leaves were adapted in dark for $1 \mathrm{~h}$, and then the measurements were performed between 9:30 and 11:00 a.m. at ambient temperatures. The leaves were saturated with pulse flashes of white light (2000 $\mu \mathrm{mol} \mathrm{m}{ }^{-2} \mathrm{~s}^{-1}$ for $3 \mathrm{~s}$ ), and for dark-adapted leaves, the Fo (minimum fluorescence) and Fm (maximal fluorescence) were measured. Besides, for light-adapted leaves, the Fs (steady-state) and $\mathrm{Fm}^{\prime}$ (maximal) fluorescence were obtained. The $\mathrm{Fo}^{\prime}$ (minimal fluorescence level in the lightadapted state) was achieved by illuminating the leaves with a 3-s flash of far-infrared light $\left(5 \mu \mathrm{mol} \mathrm{m}{ }^{-2} \mathrm{~s}^{-1}\right)$. By complying with the method of Genty et al. (1989), the maximum quantum yield of the PSII photochemistry $((\mathrm{Fm}-\mathrm{Fo}) / \mathrm{Fm})$ and the actual quantum yield of PSII electron transport $\left(\left(\mathrm{Fm}^{\prime}-\mathrm{Fs}\right) / \mathrm{Fm}^{\prime}\right)$ were determined (Genty et al. 1989). The quenching due to non-photochemical dissipation $\left(\mathrm{NPQ}=\left(\mathrm{Fm}-\mathrm{Fm}^{\prime}\right) / \mathrm{Fm}^{\prime}\right)$ and the coefficient of photochemical quenching $\left(\mathrm{qP}=\left(\mathrm{Fm}^{\prime}-\mathrm{Fs}\right) /\left(\mathrm{Fm}^{\prime}-\mathrm{Fo}^{\prime}\right)\right)$ were calculated based on the methods described previously (Maxwell and Johnson 2000).

\section{Measurement of oxidative damage}

Fresh leaves or roots $(1 \mathrm{~g})$ were homogenized in $10 \mathrm{~mL}$ $10 \mathrm{mM}$ sodium phosphate buffer ( $\mathrm{pH}$ 7.4) on an ice bath, and then the homogenate was centrifuged at $4000 \times g$ for $10 \mathrm{~min}$. The malondialdehyde (MDA) content was determined with the method presented by Janero (1990). The rates of $\mathrm{H}_{2} \mathrm{O}_{2}$ and $\mathrm{O}_{2}{ }^{*-}$ productions were determined with the method previously published by Wang and Luo (1990). The absorbance of $\mathrm{H}_{2} \mathrm{O}_{2}$ in the assay mixture was spectrophotometrically determined at $390 \mathrm{~nm}$. To analyze the $\mathrm{O}_{2}{ }^{\cdot-}$ content, $1 \mathrm{~mL} 17 \mathrm{mM}$ sulfanilic acid and 1 $\mathrm{mL} 7 \mathrm{mM} \alpha$-naphthylamine were introduced in $1 \mathrm{~mL}$ of the mixture for $20 \mathrm{~min}$ at $25^{\circ} \mathrm{C}$, and then $3 \mathrm{~mL}$ anhydrous was adopted to leach chlorophyll. The concentrations of $\mathrm{O}^{*-}$ in the assay mixture were spectrophotometrically measured at $530 \mathrm{~nm}$ (Elavarthi and Martin 2010).

\section{Determination of antioxidant enzymes}

To extract the antioxidant enzymes, the following steps were performed under ice-cold conditions. One gram of fresh leaves or roots was homogenized in $5 \mathrm{~mL} 0.1$ $\mathrm{M}$ cold Tris- $\mathrm{HCl}$ buffer ( $\mathrm{pH}$ 7.6), and the supernatant fraction was employed after being centrifugated at $10,000 \times g$ for $20 \mathrm{~min}$. The SOD activity (EC 1.15.1.1) was assayed spectrophotometrically at $560 \mathrm{~nm}$ with the method of Giannopolitis and Ries (Giannopolitis and Ries 1977). The amount of enzymes causing a 50\% decrease in SOD-inhibitable photochemical reduction of nitroblue tetrazolium (NBT) was defined as 1 U SOD activity. With the method of Aebi (Aebi 1984), CAT (EC 1.11.1.6) activity was measured spectrophotometrically at $240 \mathrm{~nm}$. A unit of CAT enzyme activity was expressed as the extinction coefficient of $1 \mu \mathrm{mol} \mathrm{H}_{2} \mathrm{O}_{2}$ oxidized $\mathrm{mg}^{-1}$ protein $\mathrm{min}^{-1}$. POD (EC 1.11.1.7) activity was assessed based on the method of guaiacol oxidation (Britton and Maehly 1955). POD was quantified spectrophotometrically at $470 \mathrm{~nm}$, in which $1 \mathrm{U}$ POD enzyme activity was the number of grams of tetraguaiacol formed per min (Zhang et al. 2017).

\section{RNA extraction and CDNA synthesis}

The total RNA was extracted from the fresh leaves and roots with Plant Total RNA Isolation Kit (Sangon Biotech, Shanghai, China) by complying with the manufacturer's instructions. To remove the residual genomic DNA, the TURBO DNA-free kit (Applied Biosystems/Ambion) was applied, and the RNA quantity was detected with a NanoDrop 2000 (Thermo Scientific, Pittsburgh, PA, USA). The complementary DNA (cDNA) was reversely 
transcribed by employing a PrimeScript RT reagent kit with gDNA eraser (Takara Bio, Dalian, China).

\section{Cloning of partial coding sequences (CDSs) of SvPCS1 and SvActin}

Based on the method of Li et al. (2010), Sophora viciifolia cDNA acted as the template to amplify the conserved sequences of SvPCS1 and SvActin. Two pairs of degenerate primers included PCS1S (5'-GAAAGGGCCTTG GAGRTGG- $\left.3^{\prime}\right) / P C S 1 A\left(5^{\prime}\right.$-GATATDAGCATR AAC CCYCT- $\left.3^{\prime}\right)$ and $A C T S\left(5^{\prime}-C T C C C A G G G C T G T G T T T C\right.$ CT-3')/ACTA (5'-CTCCATGTCATC CCAGTTGCT-3'). Twenty-five milliliters of reaction system of PCR amplification contained $12.5 \mu \mathrm{l}$ Premix Taq, one microliter $S$. viciifolia cDNA templates, $1 \mu \mathrm{l}$ of each primer, and $9.5 \mu \mathrm{l}$ RNase-Free $\mathrm{ddH}_{2} \mathrm{O}$. The PCR reactions were performed with a C1000 Thermal cycler (Bio-Rad, Hercules, CA, USA) through the procedure below: a 5-min denaturation at $94{ }^{\circ} \mathrm{C}$, followed by 35 cycles of denaturation at 94 ${ }^{\circ} \mathrm{C}$ for $30 \mathrm{~s}$, a 1 -min annealing at 54 or $55{ }^{\circ} \mathrm{C}\left(54{ }^{\circ} \mathrm{C}\right.$ for SvPCS1 conserved fragment and $55^{\circ} \mathrm{C}$ for SvActin conserved fragment), a 1-min extension at $72{ }^{\circ} \mathrm{C}$, followed by a 10 -min final extension at $72{ }^{\circ} \mathrm{C}$. Subsequently, PCR products were inserted into a pGEM-T vector (Tiangen Biotech, Beijing, China) and then transformed into Escherichia coli (strain DH5 $\alpha$ ) (Tiangen Biotech, Beijing, China). Luria-Bertani (LB) medium was adopted to select the transformants. To confirm the presence of inserts, $1 \mu \mathrm{l}$ cultured bacteria solution acted as the template DNA for PCR with primers PCSS/PCSA and ACTS/ $A C T A$. The solutions tested to be positive were applied for sequencing (Sangon Biotech, Shanghai, China).

\section{Analysis of gene expression}

Two micrograms of RNA was exploited to synthesize the first-strand cDNA. The complementary DNA (cDNA) was reversely transcribed by applying a PrimeScript RT reagent kit with gDNA eraser (Takara Bio, Dalian, China). Specific to the qRT-PCR assay, $1 \mu \mathrm{g}$ of total RNA was employed for the reverse-transcription, and $1 \mu \mathrm{L}$ of the product was applied in the PCR amplification. The reaction system employed $20 \mu \mathrm{L}$ for the qRT-PCR assay included $10 \mu \mathrm{L}$ of SYBR Premix Ex Taq (Takara Bio, Dalian, China), and the RT-PCR was performed based on CFX96 real-time PCR detection system (Bio-Rad, Hercules, CA, USA). The primers for qRTPCR here were QSvPCS1S (5'-TTGTTGCCAAGGAGC AGATA-3')/QSvPCS1A (5'-CCTGTTTCAATACCT CTTCCTT-3') and QSvACTS(5-GATGCTGAGGAT ATTCAACCC-3')/QSvACTA(5'-TTTGA CCCATCCCA ACCATAA-3') (Xu et al. 2014). The RT-PCR amplification program of $S v P C S 1$ and SvActin gene was initiated at $95{ }^{\circ} \mathrm{C}$ for $3 \mathrm{~min}$ to activate the polymerase, and then 40 cycles were performed at $95{ }^{\circ} \mathrm{C}$ for $5 \mathrm{~s}$ and $57^{\circ} \mathrm{C}$ for $30 \mathrm{~s}$. Three biological replicates were used for all genetic analyses, and relative quantification values of SvPCS1 gene were determined based on the $2^{-\triangle \triangle \mathrm{Ct}}$ method (Livak and Schmittgen 2001). All samples were technically replicated three times. Negative controls without cDNA were run within the respective analysis. In order to verify the specificity of these amplified product after the qPCR run, the analysis of melting curve was performed under the following conditions: $95^{\circ} \mathrm{C}$ for $15 \mathrm{~s}, 57^{\circ} \mathrm{C}$ for $15 \mathrm{~s}, 95^{\circ} \mathrm{C}$ for $10 \mathrm{~min}$, and then maintained at $95^{\circ} \mathrm{C}$ for $15 \mathrm{~s}$.

\section{Statistical analysis}

All experimental results received a two-way analysis of variance (ANOVA) to compare As treatments and AMF inoculation as the major factors. The respective experimental treatment contained three replicates. Noticeable differences among the mentioned treatments were assessed by performing Tukey's multiple range test. The statistical analyses were conducted by using SAS Software. Figures were generated with SigmaPlot 10.0 (Systat Software Inc., San Jose, CA, USA. https://systatsoftware. com) and the package "pheatmap" in R.

\section{Results}

\section{AMF colonization rate}

The AMF colonization was found in the roots of $R$. intraradices-inoculated $S$. viciifolia, whereas it was not detected in the non-inoculated roots (Table 1). The AMF total colonization rates of $S$. viciifolia by $R$. intraradices inoculation reached $65 \%, 56 \%$, and $43.5 \%$, and arbuscules colonization rates accounted for $33 \%, 25 \%$ and $11.5 \%$ at 0 , 50, and $100 \mathrm{mg} \mathrm{kg}^{-1}$ As levels, respectively. Notably, with the addition of As to soils, $R$. intraradices colonization was adversely affected in the $S$. viciifolia roots, which decreased with the increase in the As content in soils.

\section{Plant growth}

Plants showed the symptoms of As toxicity (e.g., leaves wilting and yellowing) when exposed to high As stress (Table 1). The shoot and root dry weight, plant height and root length of S. viciifolia seedlings, and the total chlorophyll content in leaves were reduced as the As content increased in soils $(P<0.01)$, whereas the shoot dry weight in S. viciifolia seedlings and root length in $R$. intraradices-inoculated seedlings were insignificantly different between 0 and $50 \mathrm{mg} \mathrm{kg}^{-1}$ As level.

The shoot and root dry weight, plant height and root length in S. viciifolia seedlings and the total chlorophyll content in leaves were evidently promoted by $R$. intraradices-inoculation $(P<0.05)$. Compared with 
Table 1 Effects of $R$. intraradices on AM colonization, shoot dry weight, root dry weight, plant height, and root length of S. viciifolia seedlings and the total chlorophyll content in leaves at different levels of As stress

\begin{tabular}{|c|c|c|c|c|c|c|c|c|}
\hline Inoculation & $\begin{array}{l}\text { As }(\mathrm{V}) \\
\text { treatments } \\
\mathrm{mg} \mathrm{kg}^{-1}\end{array}$ & $\begin{array}{l}\text { AM total } \\
\text { colonization } \\
\text { (\%) }\end{array}$ & $\begin{array}{l}\text { Arbuscules } \\
\text { colonization } \\
\text { (\%) }\end{array}$ & $\begin{array}{l}\text { Shoot dry } \\
\text { weight } \\
\text { (g plant }^{-1} \text { ) }\end{array}$ & $\begin{array}{l}\text { Root dry } \\
\text { weight (g } \\
\left.\text { plant }^{-1}\right)\end{array}$ & $\begin{array}{l}\text { Plant height } \\
\text { (cm) }\end{array}$ & $\begin{array}{l}\text { Root length } \\
\text { (cm) }\end{array}$ & $\begin{array}{l}\text { Total } \\
\text { chlorophyll } \\
\text { content in } \\
\text { leaves }(\mathrm{mg} / \mathrm{g} \mathrm{fw} \\
\text { of tissue) }\end{array}$ \\
\hline \multirow[t]{3}{*}{ Non-AMF } & 0 & 0 & 0 & $1.39 \pm 0.08 a b$ & $1.44 \pm 0.11 \mathrm{ab}$ & $41.40 \pm 0.94 a b$ & $31.58 \pm 1.16 a$ & $3.74 \pm 0.06 a$ \\
\hline & 50 & 0 & 0 & $1.38 \pm 0.07 a b$ & $1.32 \pm 0.13 c$ & $39.92 \pm 1.20 a b$ & $28.03 \pm 1.37 b$ & $2.65 \pm 0.09 c$ \\
\hline & 100 & 0 & 0 & $0.96 \pm 0.07 c$ & $1.05 \pm 0.06 d$ & $35.04 \pm 1.50 c$ & $23.64 \pm 1.31 \mathrm{c}$ & $1.21 \pm 0.11 \mathrm{e}$ \\
\hline \multirow[t]{3}{*}{ R. intraradices } & 0 & $65.0 \pm 5.50 a$ & $33.0 \pm 1.50 \mathrm{a}$ & $1.53 \pm 0.10 a$ & $1.54 \pm 0.12 \mathrm{a}$ & $43.85 \pm 1.37 a$ & $33.89 \pm 1.56 a$ & $3.38 \pm 0.05 b$ \\
\hline & 50 & $56.0 \pm 4.00 b$ & $25.0 \pm 2.50 b$ & $1.39 \pm 0.06 a$ & $1.44 \pm 0.11 b$ & $42.75 \pm 1.45 a$ & $32.09 \pm 0.93 a$ & $2.91 \pm 0.07 b c$ \\
\hline & 100 & $43.5 \pm 5.00 c$ & $11.5 \pm 1.00 c$ & $1.21 \pm 0.03 b$ & $1.22 \pm 0.10 c$ & $38.67 \pm 1.29 b c$ & $27.55 \pm 1.08 b$ & $1.69 \pm 0.08 d$ \\
\hline \multicolumn{9}{|l|}{ Significance } \\
\hline AMF & & $* *$ & $* *$ & NS & * & * & * & * \\
\hline AS & & & & * & $* *$ & $* *$ & * & $* *$ \\
\hline$A M F \times A S$ & & & & NS & NS & NS & NS & NS \\
\hline
\end{tabular}

The same letter in each column indicates no significant difference among treatments at $P<0.05$ using Tukey's test; values are means \pm SD, $n=3$; $P<0.05,{ }^{* *} P<0.01$, NS Not significant

non-inoculated S. viciifolia, $R$. intraradices-inoculated $S$. viciifolia seedlings achieved improvements in the shoot and root dry weight, plant height, root length, and higher total chlorophyll content in leaves, irrespective of the As treatment. Except, the root length in 0 $\mathrm{mg} \mathrm{kg}^{-1}$ As level was insignificantly different between $R$. intraradices- and non-inoculated seedlings.

The As content in S. viciifolia shoots and roots increased, and the $\mathrm{P}$ content decreased with the increase in As level in soils, regardless of the $R$. intraradices inoculation $(P<0.05)$ (Table 2$)$. The As content in S. viciifolia shoots and roots was obviously decreased and the $\mathrm{P}$ content was increased by $R$. intraradices inoculation at the identical As level in soils, except for that at $0 \mathrm{mg} \mathrm{kg}^{-1}$ As level.

\section{Gas exchange and chlorophyll fluorescence}

As stress noticeably affected the parameters of gas exchange in S. viciifolia plants $(P<0.01)$, as manifested by the depressed Pn, gs, and E, as well as the improved $\mathrm{Ci}$ (Fig. 1). However, no significant differences were identified in the Pn between 0 and $50 \mathrm{mg} \mathrm{kg}^{-1}$ As levels in $R$. intraradices-inoculated seedlings. The inoculation with $R$. intraradices in the roots of $S$. viciifolia remarkably increased Pn and gs and decreased $\mathrm{Ci}(P<0.01)$. Nevertheless, such an inoculation insignificantly affected the $\mathrm{E}$, irrespective of the $R$. intraradices-inoculation.

The Fv/Fm, ФPSII and qP in S. viciifolia leaves decreased noticeably, and the NPQ significantly increased with increasing As concentration in soils $(P<0.01)$ (Fig. 2). Besides, the ФPSII in the $R$. intraradices-inoculated

Table 2 Effects of R. intraradices on the As and P content in S. viciifolia shoots and rootsat different levels of As stress

\begin{tabular}{|c|c|c|c|c|c|}
\hline Inoculation & $\begin{array}{l}\text { As }(\mathrm{V}) \text { treatments } \\
\mathrm{mg} \mathrm{kg}^{-1}\end{array}$ & $\begin{array}{l}\text { As concentration in } \\
\text { shoots }(\mathrm{mg} / \mathrm{kg})\end{array}$ & $\begin{array}{l}\text { As concentration in } \\
\text { roots }(\mathrm{mg} / \mathrm{kg})\end{array}$ & $\begin{array}{l}\text { P concentration in } \\
\text { shoots }(\mathrm{mg} / \mathrm{g})\end{array}$ & $\begin{array}{l}\text { P concentration } \\
\text { in roots }(\mathrm{mg} / \mathrm{g})\end{array}$ \\
\hline \multirow[t]{3}{*}{ Non-AMF } & 0 & $2.55 \pm 0.22 \mathrm{e}$ & $0.24 \pm 0.11 \mathrm{e}$ & $2.35 \pm 0.13 b$ & $2.84 \pm 0.11 b$ \\
\hline & 50 & $7.43 \pm 0.48 c$ & $84.48 \pm 6.84 c$ & $1.93 \pm 0.08 c$ & $2.27 \pm 0.08 d$ \\
\hline & 100 & $13.95 \pm 0.32 \mathrm{a}$ & $176.72 \pm 6.51 \mathrm{a}$ & $1.42 \pm 0.09 d$ & $1.52 \pm 0.07 \mathrm{e}$ \\
\hline \multirow[t]{3}{*}{ R. intraradices } & 0 & $1.17 \pm 0.29 e$ & $0.28 \pm 0.05 e$ & $2.87 \pm 0.12 a$ & $3.14 \pm 0.12 a$ \\
\hline & 50 & $5.38 \pm 0.38 d$ & $66.44 \pm 4.23 d$ & $2.34 \pm 0.08 b$ & $2.71 \pm 0.13 c$ \\
\hline & 100 & $10.50 \pm 0.97 b$ & $138.39 \pm 5.78 b$ & $1.74 \pm 0.11 \mathrm{~cd}$ & $2.24 \pm 0.08 d$ \\
\hline \multicolumn{6}{|l|}{ Significance } \\
\hline AMF & & NS & NS & * & * \\
\hline AS & & * & * & * & * \\
\hline $\mathrm{AMF} \times \mathrm{AS}$ & & $* *$ & $* *$ & $* *$ & $* *$ \\
\hline
\end{tabular}

The same letter in each column indicates no significant difference among treatments at $P<0.05$ using Tukey's test; values are means $\pm \mathrm{SD}, n=3 ;{ }^{*} P<0.05,{ }^{* *} P<0.01$, NS Not significant 

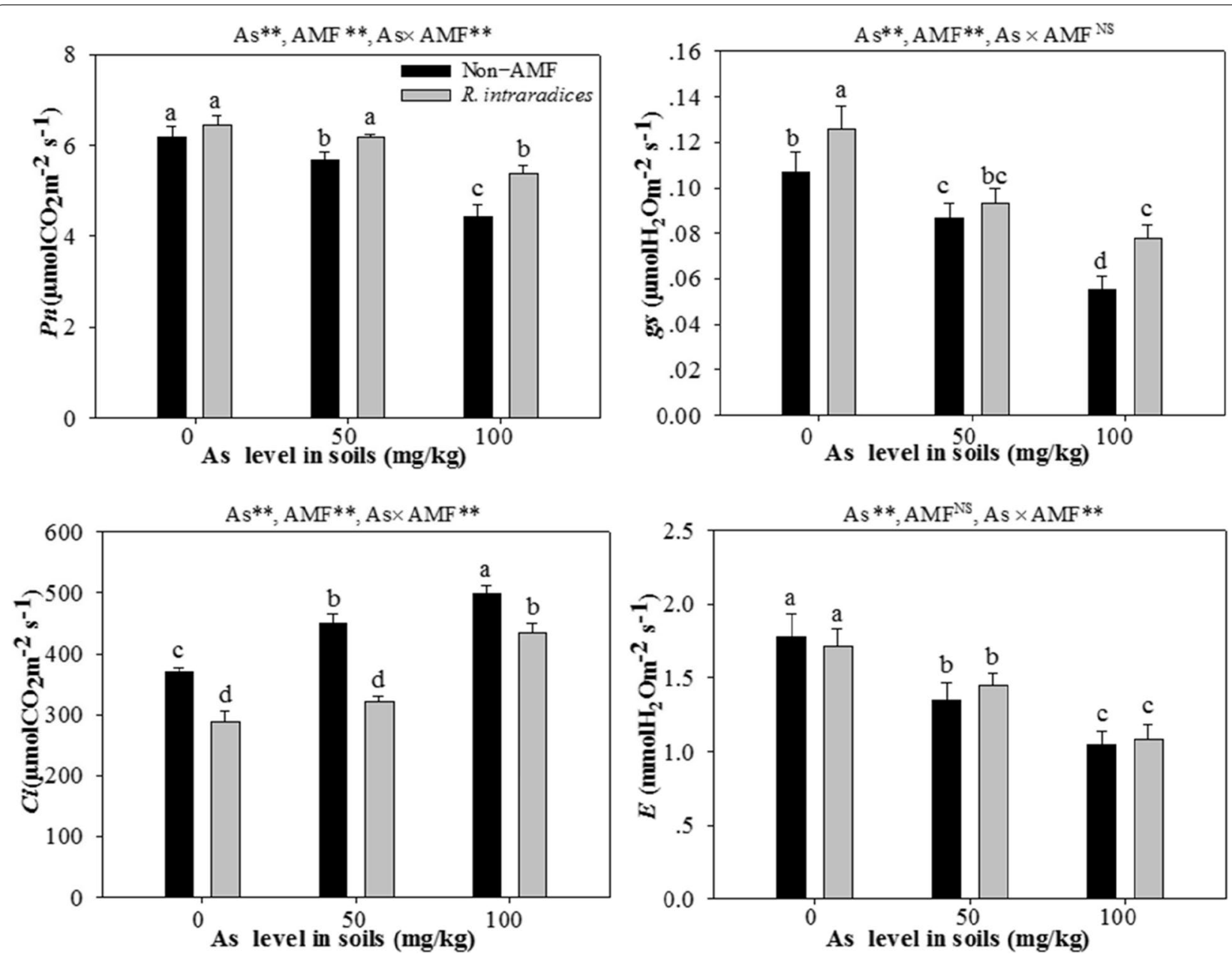

Fig. 1 Effects of Rhizophagus intraradices on net photosynthetic rate $(P n)$, stomatal conductance $\left(g_{s}\right)$, intercellular $\mathrm{CO}_{2}$ concentration $(C i)$, and transpiration rate $(E)$ in Sophora davidii leaves at different levels of As stress. Note: the same letter in each column indicates no significant difference among treatments at $P<0.05$ using Tukey's test; values are means $\pm \mathrm{SD}, n=3$; ${ }^{*}<0.05$, ${ }^{* *} P<0.01$, NS not significant

seedlings showed an apparent difference between 0 and

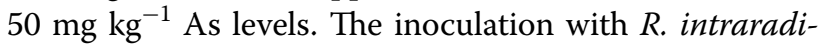
ces significantly increased the $\mathrm{Fv} / \mathrm{Fm}$, ФPSII and $\mathrm{qP}$, and decreased NPQ, as compared with non-inoculated plants at the identical As level $(P<0.01)$.

\section{Oxidative damage}

The oxidative damage in S. viciifolia leaves and roots was aggravated with the increase of As concentration in soils (Fig. 3). With the increase in the As content in soils, MDA and $\mathrm{O}_{2}{ }^{-}$content in the leaves and roots increased distinctly. $\mathrm{H}_{2} \mathrm{O}_{2}$ content in leaves were insignificantly different between 0 and $50 \mathrm{mg} \mathrm{kg}^{-1}$ As treatments. Still, the $\mathrm{H}_{2} \mathrm{O}_{2}$ content was peaked at $100 \mathrm{mg} \mathrm{kg}^{-1}$ As under $R$. intraradices- and non-inoculation conditions.

The inoculation with $R$. intraradices resulted in significantly less oxidative damage in $S$. viciifolia leaves and roots $(P<0.01)$. At 50 and $100 \mathrm{mg} \mathrm{kg}^{-1}$ As level in soils, the MDA, $\mathrm{H}_{2} \mathrm{O}_{2}$, and $\mathrm{O}_{2}{ }^{-}$content in leaves and roots decreased significantly through the $R$. intraradices-inoculation, except for the $\mathrm{H}_{2} \mathrm{O}_{2}$ content in leaves at $50 \mathrm{mg}$ $\mathrm{kg}^{-1}$ As level. At $0 \mathrm{mg} \mathrm{kg}^{-1}$ As level, no difference was identified in the MDA, $\mathrm{H}_{2} \mathrm{O}_{2}$, and $\mathrm{O}_{2}{ }^{--}$content in leaves and roots between $R$. intraradices- and non-inoculation treatments, whereas the MDA content in the roots decreased through the $R$. intraradices-inoculation.

\section{Antioxidant enzyme activities}

Regardless of whether S. viciifolia was inoculated with $R$. intraradices, the SOD, POD and CAT enzyme activities in $S$. viciifolia leaves and roots increased with the elevation of the As level $(P<0.01)$, and they were peaked at $100 \mathrm{mg} \mathrm{kg}^{-1}$ As (Fig. 4). The inoculation with $R$. intraradices evidently improved the SOD, POD, and CAT enzyme activities in leaves and roots 

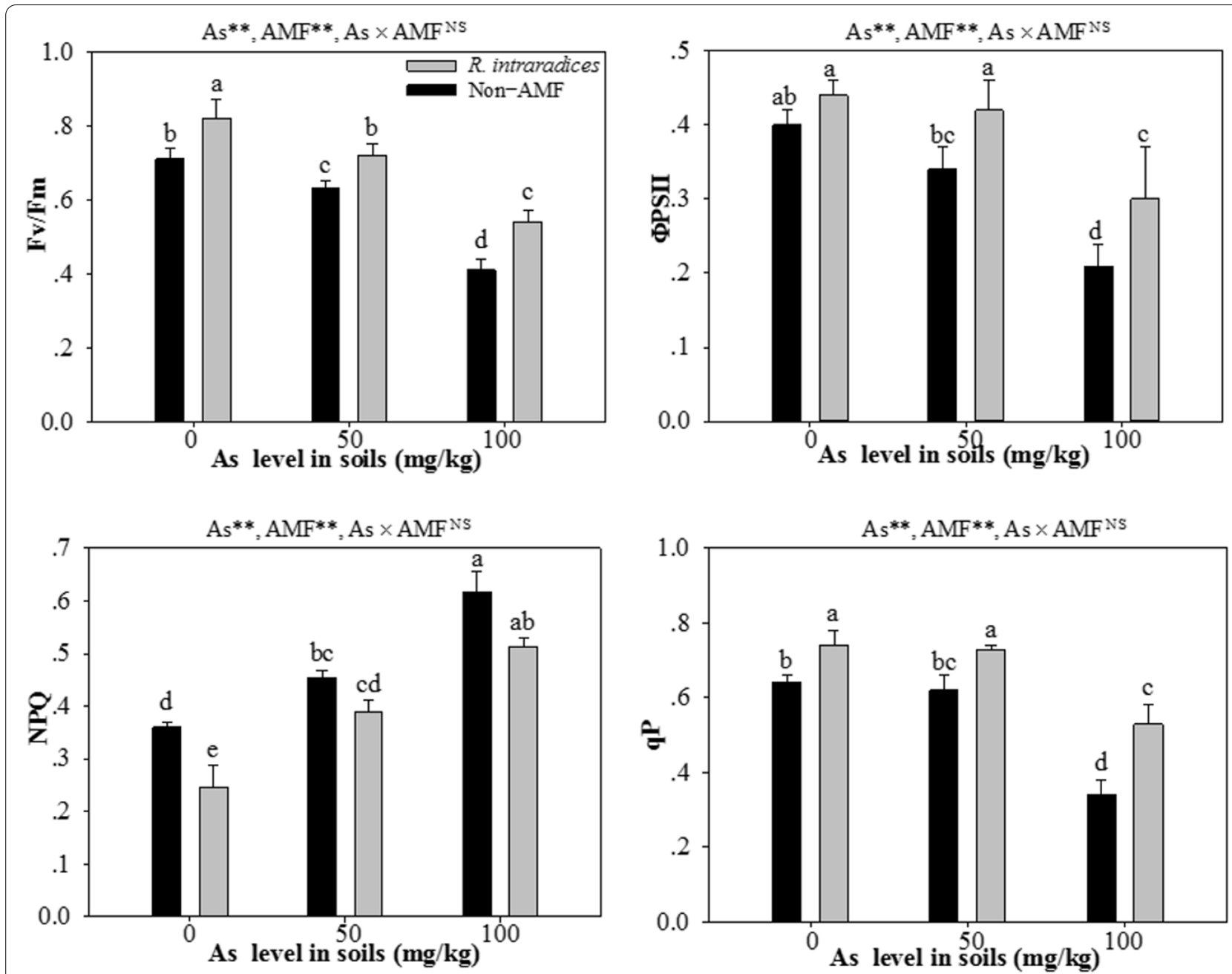

Fig. 2 Effects of Rhizophagus intraradices on maximum quantum yield in the dark-adapted state (Fv/Fm), actual quantum yield in the light-adapted steady state (DPSII), nonphotochemical quenching values (NPQ), and photochemical quenching values (qP) in Sophora davidii leaves at different levels of As stress. Note: the same letter in each column indicates no significant difference among treatments at $P<0.05$ using Tukey's test; values are means $\pm \mathrm{SD}, n=3 ;{ }^{*} P<0.05,{ }^{* *} P<0.01$, NS not significant

at 50 and $100 \mathrm{mg} \mathrm{kg}^{-1}$ As level $(P<0.01)$. However, at $0 \mathrm{mg} \mathrm{kg} \mathrm{g}^{-1}$ As level, only the enzymatic activities of SOD and POD in S. viciifolia leaves were remarkably improved through the $R$. intraradices inoculation.

\section{The gene expression of svpcs 1}

The $R$. intraradices inoculation noticeably affected the gene expression of SvPCS1 in S. viciifolia seedlings $(P<0.01)$ (Fig. 5). At the identical As level, the gene expression of SvPCS1 in the leaves and roots was distinctly up-regulated through the $R$. intraradices-inoculation. The As content in soils significantly affected the gene expression of SvPCS1 in S. viciifolia seedlings ( $P$ $<0.01)$, which was manifested as the gene expression of $S v P C S 1$ in the leaves and roots was evidently upregulated with the elevated As level in soils. In nonmycorrhizal plants, the gene expression of SvPCS1 in the leaves and roots in $100 \mathrm{mg} \mathrm{kg}^{-1}$ As levels was up-regulated through the $R$. intraradices-inoculation, whereas no obvious difference was reported between 0 and $50 \mathrm{mg} \mathrm{kg}^{-1}$ As levels. In the $R$. intraradicesinoculated $S$. viciifolia seedlings, the gene expression of SvPCS1 in the leaves and roots was highest in the $100 \mathrm{mg} \mathrm{kg}^{-1}$ As levels, and lowest in the $0 \mathrm{mg} \mathrm{kg}^{-1} \mathrm{As}$ levels. Furthermore, the expression level of SvPCS1 gene in the $R$. intraradices-inoculated roots was significantly higher than that in the leaves at the same As level treatment $(P<0.01)$. 

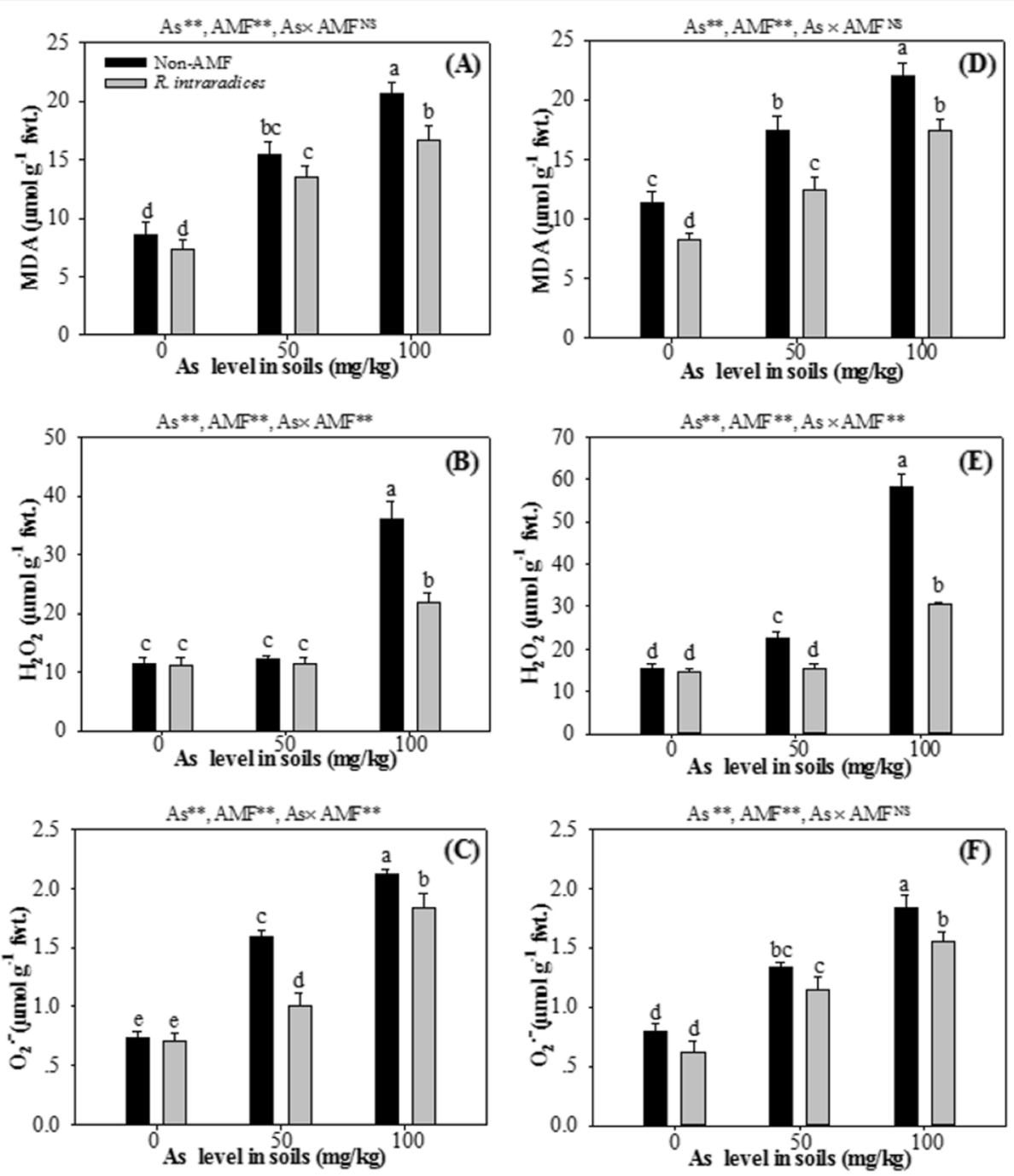

Fig 3 Effects of Rhizophagus intraradices on reactive oxygen species in Sophora davidii leaves $(\mathbf{A}, \mathbf{B}, \mathbf{C})$ and roots $(\mathbf{D}, \mathbf{E}, \mathbf{F})$ at different levels of As stress. Note: MDA: malondialdehyde, $\mathrm{H}_{2} \mathrm{O}_{2}$ : hydrogen peroxide, $\mathrm{O}_{2}^{--}$: superoxide anion. The same letter in each column indicates no significant difference among treatments at $P<0.05$ using Tukey's test; Values are means $\pm \mathrm{SD}, n=3$; ${ }^{*} P<0.05$, ${ }^{* *} P<0.01$, NS not significant

\section{Discussion}

The AMF colonization rate in S. viciifolia roots decreased with the elevation of As content in soil in our study. Similar As negative effects on AMF colonization were previously found in other host plants, such as Glycine max L. (Spagnoletti and Lavado 2015), Lolium perenne L. (Dong et al. 2008), and Helianthus annuus L. (Ultra et al. 2007). However, some studies reported no decrease in the AMF colonization rate (Christophersen et al. 2009) and also an increase (Al Agely et al. 2005) when the As solution was artificially introduced into soils. Despite such a difference of AMF colonization rate to As stress, each AMF symbiosis could contribute to host plants (Sharma et al. 2017). Our results indicated that As negatively affected the AMF colonization in the rhizosphere soil of S. viciifolia roots. When exposed to As toxicity, plants produced more root exudates, thus the plant supply of carbonaceous compounds to AMF was reduced, which hampered the AMF pre-symbiotic process, such as decrease in spore germination and hyphal growth in plant rhizosphere (Spagnoletti et al. 2017; Spagnoletti and Lavado 2015).

The efficiency of AMF-inoculation for plant against HM stress could be visually indicated by plant biomass (Chen et al. 2015). High As levels in soils often jeopardized the normal plant growth, and some toxicity symptoms (e.g., biomass decrease, stagnation in plant growth, wilting, and necrosis of leaf blades) could be shown (De Andrade et al. 2015; Srivastava and Sharma 2013). In this 

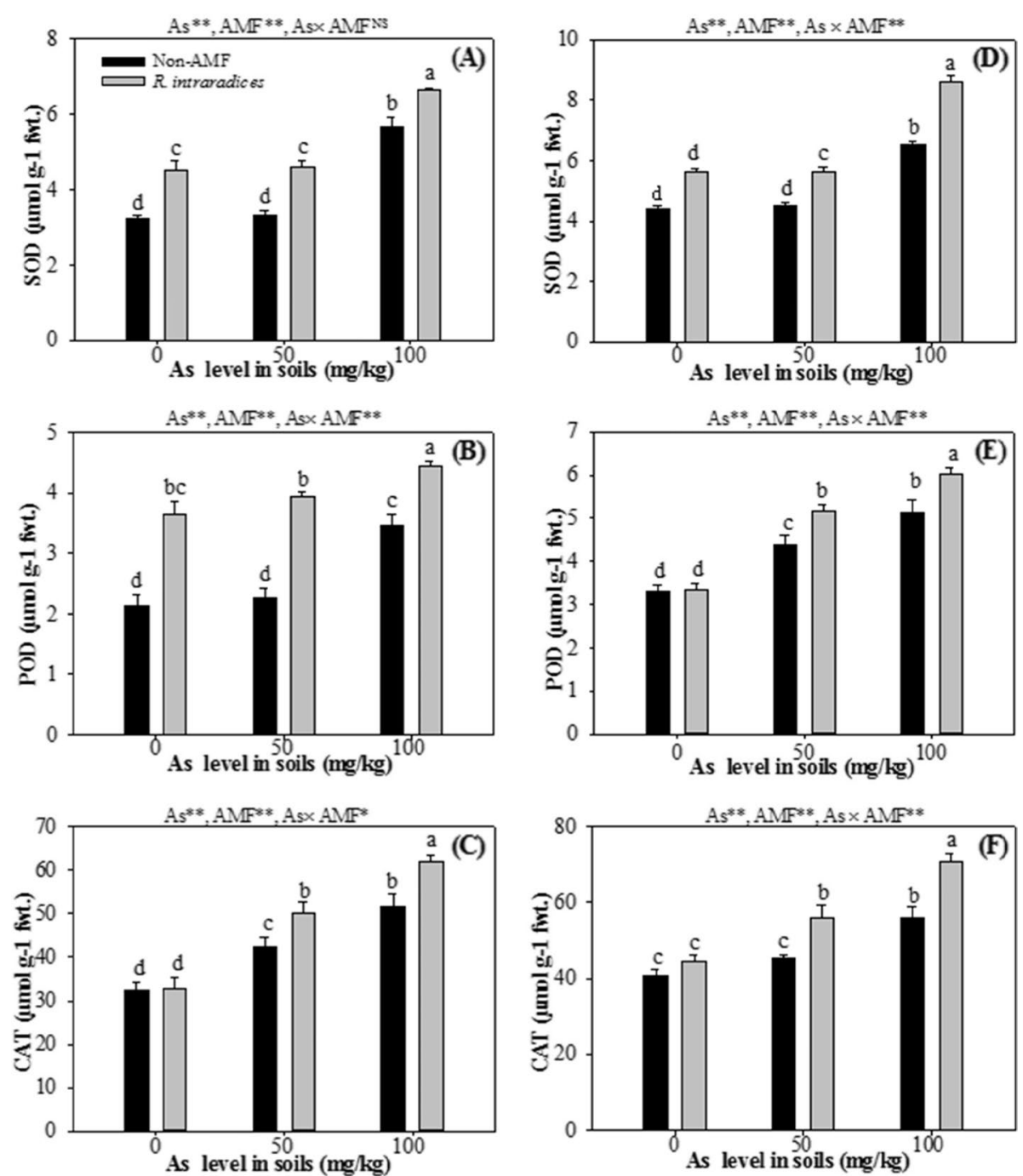

Fig. 4 Effects of Rhizophagus intraradices on antioxidant enzyme in Sophora davidii leaves (A-C) and roots (D-F) at different levels of As stress. Note: SOD: superoxide dismutase, POD: peroxidase, CAT: catalase. The same letter in each column indicates no significant difference among treatments at $P<0.05$ using Tukey's test; values are means $\pm \mathrm{SD}, n=3 ;{ }^{*} P<0.05,{ }^{*} P<0.01$, NS not significant

study, the growth parameters of S. viciifolia seedlings were reduced with the increase of As content in soils. But the $R$. intraradices-inoculated $S$. viciifolia grew better than non-inoculated seedlings at all As levels, which suggested that the $R$. intraradices symbiosis could play a positive role on mitigating As stress in S. viciifolia seedlings. This result was consistent with other previous studies which showed biomass losses in plants by high As toxicity and also proved the role of AMF in improving the As tolerance by increasing plant growth (Christophersen et al. 2009; Das et al. 2017a, b; De Andrade et al. 2015). The improved parameters of plant growth under As stress were closed due to improved mineral nutrition via
AMF extraradical hyphal networks (Ahmed et al. 2006; Garg and Chandel 2011).

As and $\mathrm{P}$ belonged to the same family in the periodic table of chemical element, both of them had the similar chemical property in nature, and competed for the same transport systems on plant cell membrane (Li et al. 2019). In the present study, the As contents in the roots and shoots of $R$. intraradices-inoculated S. viciifolia were significantly lower, and the P content were higher than those of non-inoculated seedlings. AMF-inoculated plants kept a higher P:As ratio, consequently prevented replacement of $\mathrm{P}$ by As in the process of photophosphorylation for the synthesis of ATP, ultimately As-induced negative impact 


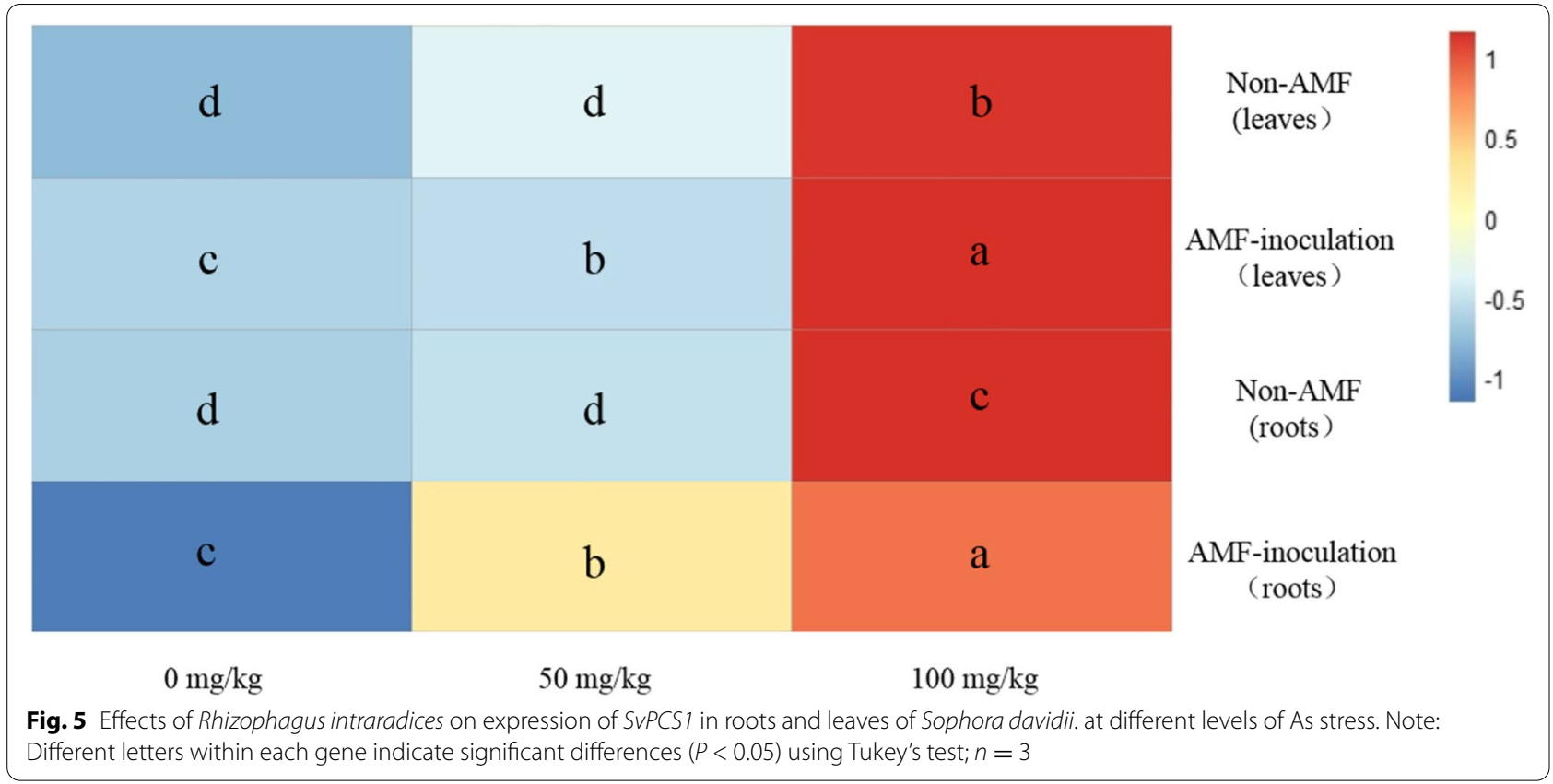

on photosynthesis were alleviated in AMF-inoculated plants (Sharma et al. 2017). Our results also found that the shoot and root dry weight, plant height and root length in the $R$. intraradices-inoculated S. viciifolia seedlings were distinctly improved as compared with those in the non-inoculated seedlings under As stress. Our results suggested that $R$. intraradices symbiosis increased $\mathrm{P}$ absorption, reduced As content in plant tissues and promoted the growth of host plants, which were concordant with other reports (Gonzalez-Chavez et al. 2002; Sharples et al. 2000; Zhang et al. 2020). The lower As content and the greater biomass of the AMF-inoculated seedlings in this study verified the previously mentioned mechanism of "growth dilution effect" (Chen et al. 2015; Li et al. 2018; Spagnoletti and Lavado 2015).

To avoid oxidative damages, plants were equipped with antioxidant enzymes system that could cope with the accumulation of ROS in plants. Funneliformis mosseae and Diversispora spurcum inoculation decreased the $\mathrm{H}_{2} \mathrm{O}_{2}$ and MDA contents and enhanced SOD and CAT) activities in maize leaves under multiple $\mathrm{HM}(\mathrm{Pb}, \mathrm{Zn}, \mathrm{Cd}$, and As) stress (Zhan et al. 2018). Similarly, R. intraradices and Glomus etunicatum inoculation were reported to improving the As tolerance by increasing the antioxidant enzyme activity and antioxidant content in wheat (Sharma et al. 2017). In this study, $R$. intraradices inoculated S. viciifolia displayed the lower $\mathrm{H}_{2} \mathrm{O}_{2}, \mathrm{O}_{2}{ }^{--}$, and MDA levels, and showed the higher antioxidant activities of SOD, CAT and POD than the non-inoculated seedlings under As stress. Enhanced activities of antioxidant enzymes may be due to higher uptake of these micronutrients and lower cellular As distribution in AMF-inoculated plants (Spagnoletti et al. 2016). Thus, a decrease in the oxidative damage and an improvement in antioxidant enzymes could act as the vital strategies by which AMF protect host plants against As stress.

AMF symbiosis enhanced the photosynthesis of host plants under stress conditions, due to higher gas exchange rates and efficiencies by means of mycelia growth and respiration (Kaschuk et al. 2009). In this study, the inoculation with $R$. intraradices increased the $P n, g s$ and $E$, and such an inoculation also decreased $C i$ in S. viciifolia leaves under As stress, which indicated that $R$. intraradices inoculation improved the photosynthesis of S. viciifolia under As stress. The Pn increase through the AMF inoculation was related to a higher $g s$ in AMFinoculated seedlings than that in non-inoculated plants (Chen et al. 2015). Other reports also showed that the $R$. irregularis inoculation tended to increase the $\mathrm{E}$ and gs in rice leaves under As exposure (De Andrade et al. 2015).

The effects of $R$. intraradices inoculation on the photochemical capacities of $S$. viciifolia leaves under As stress were assessed by using a chlorophyll fluorescence analysis. The Fv/Fo value, representing the photochemical capacity of PSII in plants, indicated the quantity and size of the active photosynthetic centers in the chloroplasts (Xu et al. 2014). In the present study, the Fv/Fm exceeded 0.8 in the $R$. intraradices-inoculated seedlings without As stress, and it was still lower than 0.8 in all of the plants under As stress, which indicated that As 
stress caused the chronic photoinhibition and impaired the photochemical activity in S. viciifolia leaves. The PSII and $\mathrm{qP}$ in S. viciifolia leaves decreased with the increase in As content, but both were higher in $R$. intraradices-inoculated seedlings than in non-inoculated seedlings, which were related to down-regulate the electron transport rate of PSII by As toxicity and to elevate the electron transport rate by AMF symbiosis (De Andrade et al. 2015). It was reported that $R$. intraradices improved the efficiency of PSII photochemistry and reduced the adverse effect of $\mathrm{Pb}$ stress on photosynthesis in S. viciifolia (Xu et al. 2014). The increased Fv/Fm and PSII in AMF-inoculated S. viciifolia suggested an improved efficiency of PSII photochemistry, compared with that of non-inoculated S. viciifolia, other studies identified the similar results, which showed that AMF symbiosis improved the performance of photosynthesis-related processes in rice under As stress (De Andrade et al. 2015). In our study, the NPQ significantly increased with the improvement of the As level in soils, but decreased by $R$. intraradices-inoculation. It indicated AMF symbiosis alleviated the photoinhibition and possibly restored oxidative damages to the chloroplasts. The improved photosynthetic capacity in AMF-inoculated maize under salt stress were observed, due to higher gas exchange and photochemical and non-photochemical efficiencies (Sheng et al. 2008). In our study, AMF symbiosis enhanced photosynthesis of S. viciifolia seedlings under As stress by improving the efficiency of PSII photochemistry to use light energy and transport the electron.

$P C s$ played a pivotal role in the homeostasis, the immobilization and the transportation for some $\mathrm{HMs}$ (e.g., $\mathrm{Cu}, \mathrm{Pb}$, and $\mathrm{Zn}$ ) (Xu et al. 2014). The elevated HM content and the present GSH in the cytoplasm of plants activated the PCS enzyme, on that basis, the PCs biosynthesis was initiated (Xu et al. 2014). The expressions level of plant $P C s$ genes were also proved to be regulated under some HM stresses, but the expression patterns were still controversial. The gene expression of SvPCS1 in S. viciifolia leaves and roots was evidently up-regulated with the elevated As level in soils in this study. The regulating expression of PCS gene in plants complied with the requirement of resilient defense against different HMs (De Andrade et al. 2015). The gene expression of tobacco phytochelatin synthase (NtPCS1) exhibited the increased tolerance to As stress (Lee and Hwang 2015). The exposure to high As stress induced the overexpression of $P C S$ catalyzing the formation of PCs, while the PCs-As complex alleviated the stress by chelating and transferring As ions from the cytoplasm into vacuole (De Andrade et al. 2015).
In this study, SvPCS1 expressed both in non- and $R$. intraradices-inoculated $S$. viciifolia seedlings, and $R$. intraradices-inoculation noticeably up-regulated the expression of $S v P C S 1$, which was attributed to the lower As toxicity in the cytoplasm of $R$. intraradices-inoculated root cells, compared with non-inoculated ones (Xu et al. 2014). Christophersen et al. (2012) also found that both $R$. intraradices and $F$. mosseae inoculated Medicago truncatula. had higher expressions of MtPCS than non-mycorrhizal plants under As stress.

\section{Conclusion}

In this study, excessive As in soils exerted the multiple negative effects on various physiological and biochemical parameters of S. viciifolia seedlings. However, $R$. intraradices symbiosis improved the plant biomass, gas exchange, chlorophyll fluorescence, activities of antioxidant enzymes, and upregulated the expression of SvPCS1in S. viciifolia seedlings, which suggested that the significant role of $R$. intraradices in improving the growth performance of $S$. viciifolia seedlings under As stress. Thus, this study demonstrated AMF inoculation was a feasible way to improve the As tolerance on woody leguminous species. The inoculation with AMF in woody leguminous may be a viable technology in phytoremediation and land reclamation in As-contaminated areas.

\section{Abbreviations}

AMF: Arbuscular mycorrhizal fungi; As: Arsenic; Pn: The photosynthetic rate; $g s:$ The stomatal conductance; E: The transpiration rate; Fv/Fm: The maximal photochemical efficiency of PSII photochemistry; DPSII: The actual quantum yield; $q$ P: The photochemical quenching values; MDA: Malondialdehyde; $\mathrm{O}_{2}{ }^{-}$ Superoxide radical; ROS: Reactive oxygen species; $\mathrm{H}_{2} \mathrm{O}_{2}$ : Hydrogen peroxide; HMs: Heavy metals; SOD: Superoxide dismutase; POD: Peroxidase; CAT: Catalase; PSII: Photosystem II; PCs: Phytochelatins; GSH: Tri-peptide glutathione; K: Potassium; P: Phosphorus; N: Nitrogen; Cd: Cadmium; GiPT: High-affinity Pi/As transporter; Fs: The steady-state fluorescence; Fm': The maximal fluorescence; Fo': The minimal fluorescence level in the light-adapted state; (Fm-Fo)/Fm: The maximum quantum yield of the PSII photochemistry; $\left(\mathrm{Fm}^{\prime}-\mathrm{Fs}\right) / \mathrm{Fm}^{\prime}$ : The actual quantum yield of PSII electron transport; NPQ: The quenching due to nonphotochemical dissipation; qP: The coefficient of photochemical quenching; CDSs: Cloning of partial coding sequences; PCR: Polymerase chain reaction; ANOVA: Analysis of variance; PCS: Phytochelatin synthase.

\section{Acknowledgements}

We thank anonymous reviewers for their valuable suggestion to improve this manuscript.

\section{Authors' contributions}

Minggui Gong designed research and experiments. Qiaoming Zhang and Yanan Wei wrote the main manuscript text. Jiangfeng yuan and Shanshan Xu performed the plant pot experiment. Qingshan Chang provided critical reading and revising suggestion. All authors read, reviewed, and approved the manuscript.

\section{Funding}

This study was financially supported by the National Natural Science Foundation of China (Nos. 31870093 and 31800096) and by the Science Foundation of Henan Province, China (Nos. 182300410050 and 182300410082). 


\section{Availability of data and materials \\ N/A}

\section{Declarations}

\section{Ethics approval and consent to participate}

N/A

\section{Consent for publication}

All the authors have approved the manuscript that is enclosed.

\section{Competing interests}

The authors declare that they have no competing interests.

\section{Author details}

${ }^{1}$ College of Horticulture and Plant Protection, Henan University of Science and Technology, Luoyang 471023, Henan, China. ${ }^{2}$ College of Food and Bioengineering, Henan University of Science and Technology, Luoyang 471023, Henan, China.

Received: 25 November 2021 Accepted: 15 February 2022

Published online: 02 March 2022

\section{References}

Aebi H (1984) Catalase in vitro. Method Enzymol 105:121-126. https://doi.org/ 10.1016/S0076-6879(84)05016-3

Ahmad P, Jamsheed S, Hameed A, Rasool S, Sharma I, Azooz MM, Hasanuzzaman M (2014) Drought stress induced oxidative damage and antioxidants in plants. In: Oxidative damage to plants. Academic, pp 345-367. https://doi.org/10.1016/B978-0-12-799963-0.00011-3

Ahmed FRS, Killham K, Alexander I (2006) Influences of arbuscular mycorrhizal fungus Glomus mosseae on growth and nutrition of lentil irrigated with arsenic contaminated water. Plant Soil 283(1-2):33-41. https://doi.org/10. 1007/s11104-005-0415-8

Al Agely A, Sylvia DM, Ma LQ (2005) Mycorrhizae increase arsenic uptake by the hyperaccumulator Chinese Brake Fern (L.). J Environ Qual 34(6):2181. https://doi.org/10.2134/jeq2004.0411

Chance B, Maehly AC (1955) Assay of catalases and peroxidases. Methods Enzymol 2:764-775. https://doi.org/10.1016/s0076-6879(55)02300-8

Chen LH, Hu XW, Yang WQ, Xu ZF, Zhang DJ, Gao S (2015) The effects of arbuscular mycorrhizal fungi on sex-specific responses to $\mathrm{Pb}$ pollution in Populus cathayana. Environ Saf 113:460-468. https://doi.org/10.1016/j. ecoenv.2014.12.033

Christophersen HM, Smith FA, Smith SE (2009) Arbuscular mycorrhizal colonization reduces arsenate uptake in barley via downregulation of transporters in the direct epidermal phosphate uptake pathway. New Phytol 184(4):962-974. https://doi.org/10.1111/j.1469-8137.2009.03009.x

Cicatelli A, Lingua G, Todeschini V, Biondi S, Torrigiani P, Castiglione S (2012) Arbuscular mycorrhizal fungi modulate the leaf transcriptome of a Populus alba L. clone grown on a zinc and coppercontaminated soil. Environ Exp Bot 75:25-35. https://doi.org/10.1016/j.envexpbot.2011.08.012

Das N, Bhattacharya S, Bhattacharyya S, Maiti MK (2017a) Identification of alternatively spliced transcripts of rice phytochelatin synthase 2 gene OSPCS2 involved in mitigation of cadmium and arsenic stresses. Plant Mol Biol 94(1-2):167-183. https://doi.org/10.1007/s11103-017-0600-1

Das S, Chou ML, Jean JS, Yang HJ, Kim PJ (2017b) Arsenic enrichment enhanced root exudates and altered rhizosphere microbial communities and activities in hyperaccumulator Pteris vittata. J Hazard Mater 325:279-287. https://doi.org/10.1016/j.jhazmat.2016.12.006

De Andrade SAL, Domingues AP, Mazzafera P (2015) Photosynthesis is induced in rice plants that associate with arbuscular mycorrhizal fungi and are grown under arsenate and arsenite stress. Chemosphere 134:141-149. https://doi.org/10.1016/j.chemosphere.2015.04.023

Dong Y, Zhu YG, Smith FA, Wang Y, Chen B (2008) Arbuscular mycorrhiza enhanced arsenic resistance of both white clover (Trifolium repens Linn.) and ryegrass (Lolium perenne L.) plants in an arsenic-contaminated soil. Environ Pollut 155(1):174-181. https://doi.org/10.1016/j.envpol.2007.10.023
Elavarthi S, Martin B (2010) Spectrophotometric assays for antioxidant enzymes in plants. In: Plant stress tolerance, vol 639. Humana Press, pp 273-280. https://doi.org/10.1007/978-1-60761-702-0_16

Garg N, Chandel S (2011) Role of Arbuscular mycorrhizal (AM) fungi on growth, cadmium uptake, osmolyte, and phytochelatin synthesis in Cajanus cajan (L.) Millsp. under NaCl and Cd stresses. J Plant Growth Regul 31(3):292308. https://doi.org/10.1007/s00344-011-9239-3

Gaude N, Bortfeld S, Duensing N, Lohse M, Krajinski F (2012) Arbusculecontaining and non-colonized cortical cells of mycorrhizal roots undergo extensive and specific reprogramming during arbuscular mycorrhizal development. Plant J 69(3):510-528. https://doi.org/10.1111/j.1365-313X. 2011.04810.x

Genty B, Briantais JM, Baker NR (1989) The relationship between the quantumyield of photosynthetic electron transport and quenching of chlorophyll fluorescence. Biochem Biophys Acta 990(1):87-92. https://doi.org/ 10.1016/S0304-4165(89)80016-9

Giannopolitis CN, Ries SK (1977) Superoxide dismutases: i. occurrence in higher plants. Plant Physiol 59(2):309-314. https://doi.org/10.1104/pp. 59.2.309

Giovannetti M, Mosse B (1980) An evaluation of techniques for measuring vesicular arbuscular mycorrhizal infection in roots. New Phytol 84(3):489500. https://doi.org/10.1111/j.1469-8137.1980.tb04556.x

Gomes MP, Moura PAS, Nascentes CC, Scotti MR (2015) Arbuscular mycorrhizal fungi and arsenate uptake by brachiaria grass (Brachiaria decumbens). Bioremediat J 19(2):151-159. https://doi.org/10.1080/10889868.2014. 938726

Gong MG, Tang M, Chen H, Zhang QM, Feng X (2013) Effects of two Glomus species on the growth and physiological performance of Sophora davidii seedlings underwater stress. New For 44(3):399-408. https://doi.org/10. 1007/s11056-012-9349-1

Gonzalez-Chavez C, Harris PJ, Dodd J, Meharg AA (2002) Arbuscular mycorrhizal fungi confer enhanced arsenate resistance on Holcus lanatus. New Phytol 155(1):163-171. https://doi.org/10.1046/j.1469-8137.2002.00430.x

González-Chávez MDCA, del Pilar Ortega-Larrocea M, Carrillo-González R, López-Meyer M, Xoconostle-Cázares B, Gomez SK, Maldonado-Mendoza IE (2011) Arsenate induces the expression of fungal genes involved in As transport in arbuscular mycorrhiza. Fungal Biol-UK 115(12):1197-1209. https://doi.org/10.1016/j.funbio.2011.08.005

Hoagland M, Arnon D (1950) The water culture method for growing plants without soil. Calif Agric Exp St 347:1950. https://doi.org/10.1016/S01406736(00)73482-9

Hogekamp C, Arndt D, Pereira PA, Becker JD, Hohnjec N, Kuster H (2011) Laser microdissection unravels cell-type-specific transcription in arbuscular mycorrhizal roots, including CAAT-box transcription factor gene expression correlating with fungal contact and spread. Plant Physiol 157(4):2023-2043. https://doi.org/10.1104/pp.111.186635

Janero DR (1990) Malondialdehyde and thiobarbituric acid-reactivity as diagnostic indices of lipid peroxidation and peroxidative tissue injury. Free Radic Biol Med 9(6):515-540. https://doi.org/10.1016/0891-5849(90)90131-2

Kaschuk G, Kuyper TW, Leffelaar PA, Hungria M, Giller KE (2009) Are the rates of photosynthesis stimulated by the carbon sink strength of rhizobial and arbuscular mycorrhizal symbioses? Soil Biol Biochem 41(6):1233-1244. https://doi.org/10.1016/j.soilbio.2009.03.005

Lee BD, Hwang S (2015) Tobacco phytochelatin synthase (NtPCS1) plays important roles in cadmium and arsenic tolerance and in early plant development in tobacco. Plant Biotechnol Rep 9(3):107-114. https://doi. org/10.1007/s11816-015-0348-5

Li JL, Sun YQ, Zhang X, Hu YJ, Li T, Zhang XM, Chen BD (2018) A methyltransferase gene from arbuscular mycorrhizal fungi involved in arsenic methylation and volatilization. Chemosphere 209:392-400. https://doi.org/10. 1016/j.chemosphere.2018.06.092

Li MG, Stragliati L, Bellini E, Ricci A, Saba A, Sanità di Toppi L, Varotto C (2019) Evolution and functional differentiation of recently diverged phytochelatin synthase genes from Arundodonax (L.). J Exp Bot 70(19):5391-5405. https://doi.org/10.1093/jxb/erz266

Liu Y, Zhu YG, Chen BD, Christie P, Li XL (2005) Yield and arsenate uptake of arbuscular mycorrhizal tomato colonized by Glomus mosseae BEG167 in As spiked soil under glasshouse conditions. Environ Int 31(6):867-873. https://doi.org/10.1016/j.envint.2005.05.041 
Livak KJ, Schmittgen TD (2001) Analysis of relative gene expression data using realtime quantitative PCR and the $2^{-\Delta \Delta C t}$ method. Methods 25(4):402408. https://doi.org/10.1006/meth.2001

Luo ZB, He J, Polle A, Rennenberg H (2016) Heavy metal accumulation and signal transduction in herbaceous and woody plants: Paving the way for enhancing phytoremediation efficiency. Biotechnol Adv 34(6):1131-1148. https://doi.org/10.1016/j.biotechadv.2016.07.003

Maxwell K, Johnson GN (2000) Chlorophyll fluorescence-a practical guide. J Exp Bot 51(345):659-668. https://doi.org/10.1093/jexbot/51.345.659

Phillips JM, Hayman DS (1970) Improved procedures for clearing roots and staining parasitic and vesicular arbuscular mycorrhizal fungi for rapid assessment of infection. Trans Br Mycol Soc 55(1):158-161. https://doi. org/10.1016/S0007-1536(70)80110-3

Riley R, Corradi N (2013) Searching for clues of sexual reproduction in the genomes of arbuscular mycorrhizal fungi. Fungal Ecol 6(1):44-49. https:// doi.org/10.1016/j.funeco.2012.01.010

Sharma S, Anand G, Singh N, Kapoor R (2017) Arbuscular mycorrhiza augments arsenic tolerance in wheat (Triticum aestivum L.) by strengthening antioxidant defense system and thiol metabolism. Front Plant Sci 8:1-21. https://doi.org/10.3389/fpls.2017.00906

Sharples JM, Meharg AA, Chambers SM, Cairney JWG (2000) Evolution: symbiotic solution to arsenic contamination. Nature 404(6781):951-952. https://doi.org/10.1038/35010193

Shi YZ, Zhang XL, Xu SX, Lan ZJ, Chan YL (2017) Mycorrhizal relationship in lupines: a review. Legume Res 40(6):965-973. https://doi.org/10.18805/Ir. v40i04.9013

Smith SE, Read DJ (2008) Mycorrhizal symbiosis, 3rd edn. Academic, San Diego Spagnoletti F, Carmona M, Gómez NET, Chiocchio V, Lavado RS (2017) Arbuscular mycorrhiza reduces the negative effects of M. phaseolina on soybean plants in arsenic-contaminated soils. Appl Soil Ecol 121:41-47. https://doi.org/10.1016/j.apsoil.2017.09.019

Spagnoletti F, Lavado RS (2015) The arbuscular mycorrhiza Rhizophagus intraradices reduces the negative effects of arsenic on soybean plants. Agronomy 5(2):188-199. https://doi.org/10.3390/agron omy5020188

Spagnoletti FN, Balestrasse K, Lavado RS, Giacometti R (2016) Arbuscular mycorrhiza detoxifying response against arsenic and pathogenic fungus in soybean. Ecotoxicol Environ Saf 133:47-56. https://doi.org/10.1016/j. ecoenv.2016.06.012

Srivastava S, Mishra S, Tripathi RD, Dwivedi S, Trivedi PK, Tandon PK (2007) Phytochelatins and antioxidant systems respond differentially during arsenite and arsenate stress in Hydrilla verticillata (L.f.) royle. Environ Sci Technol 41(8):2930-2936. https://doi.org/10.1021/es062167j

Srivastava S, Sharma YK (2013) Impact of arsenic toxicity on black gram and its amelioration using phosphate. ISRN Toxicol 2013:1-8. https://doi.org/10. $1155 / 2013 / 340925$

Ultra VUY, Tanaka S, Sakurai K, Iwasaki K (2007) Arbuscular mycorrhizal fungus (Glomus aggregatum) influences biotransformation of arsenic in the rhizosphere of sunflower (Helianthus annuus L.). Soil Sci Plant Nutr 53(4):499-508. https://doi.org/10.1111/j.1747-0765.2007.00143.x

Wang AG, Luo GH (1990) Quantitative relation between the reaction of hydroxylamine and superoxide anion radicals in plants. Plant Physiol Commun 26:55-57 (in Chinese with English abstract)

Xu ZY, Ban YH, Li Z, Chen H, Yang R, Tang M (2014) Arbuscular mycorrhizal fungi play a role in protecting roots of Sophora viciifolia Hance. from $\mathrm{Pb}$ damage associated with increased phytochelatin synthase gene expression. Environ Pollut Res Int 21(22):12671-12683. https://doi.org/10.1007/ s11356-014-3209-9

Yu Y, Zhang S, Huang H, Lou L, Wen B (2009) Arsenic accumulation and speciation in maize as affected by inoculation with arbuscular mycorrhizal fungus glomus mosseae. J Agr Food Chem 57(9):3695-3701. https://doi. org/10.1021/jf900107y

Zhan F, Li B, Jiang M, Yue X, He Y, Xia Y, Wang Y (2018) Arbuscular mycorrhizal fungi enhance antioxidant defense in the leaves and the retention of heavy metals in the roots of maize. Environ Sci Pollut R 25(24):2433824347. https://doi.org/10.1007/s11356-018-2487-z

Zhang Q, Gong M, Liu K, Chen Y, Yuan J, Chang Q (2020) Rhizoglomus intraradices improves plant growth, root morphology and phytohormone balance of Robinia Pseudoacacia in arsenic-contaminated soils. Front Microbiol 11. https://doi.org/10.3389/fmicb.2020.01428
Zhang QM, Gong MG, Yuan JF, Hou Y, Zhang HM, Wang Y, Hou X (2017) Dark septate endophyte improves drought tolerance in Sorghum. Int J Agric Biol 19(1):53-60. https://doi.org/10.17957/IJAB/15.0241

Zou YN, Huang YM, Wu QS, He XH (2015) Mycorrhiza-induced lower oxidative burst is related with higher antioxidant enzyme activities, net $\mathrm{H}_{2} \mathrm{O}_{2}$ effluxes, and $\mathrm{Ca}^{2+}$ influxes in trifoliate orange roots under drought stress. Mycorrhiza 25(2):143-152. https://doi.org/10.1007/s00572-014-0598-z

\section{Publisher's Note}

Springer Nature remains neutral with regard to jurisdictional claims in published maps and institutional affiliations.

Ready to submit your research? Choose BMC and benefit from:

- fast, convenient online submission

- thorough peer review by experienced researchers in your field

- rapid publication on acceptance

- support for research data, including large and complex data types

- gold Open Access which fosters wider collaboration and increased citations

- maximum visibility for your research: over 100M website views per year

At BMC, research is always in progress.

Learn more biomedcentral.com/submissions 